\title{
Front Matter: Volume 8058
}

, "Front Matter: Volume 8058," Proc. SPIE 8058, Independent Component Analyses, Wavelets, Neural Networks, Biosystems, and Nanoengineering IX, 805801 (29 June 2011); doi: 10.1117/12.899780

SDIE Event: SPIE Defense, Security, and Sensing, 2011, Orlando, Florida, United SPIE. States 


\section{PROCEEDINGS OF SPIE}

\section{Independent Component Analyses, Wavelets, Neural Networks, Biosystems, and Nanoengineering IX}

Harold Szu

Liyi Dai

Editor

27-29 April 2011

Orlando, Florida, United States

Sponsored and Published by

SPIE

Volume 8058 
The papers included in this volume were part of the technical conference cited on the cover and title page. Papers were selected and subject to review by the editors and conference program committee. Some conference presentations may not be available for publication. The papers published in these proceedings reflect the work and thoughts of the authors and are published herein as submitted. The publisher is not responsible for the validity of the information or for any outcomes resulting from reliance thereon.

Please use the following format to cite material from this book:

Author(s), "Title of Paper," in Independent Component Analyses, Wavelets, Neural Networks, Biosystems, and Nanoengineering IX, edited by Harold SzU, Liyi Dai, Proceedings of SPIE Vol. 8058 (SPIE, Bellingham, WA, 2011) Article CID Number.

ISSN 0277-786X

ISBN 9780819486325

Published by

SPIE

P.O. Box 10, Bellingham, Washington 98227-0010 USA

Telephone +1 3606763290 (Pacific Time) · Fax +1 3606471445

SPIE.org

Copyright (C) 2011, Society of Photo-Optical Instrumentation Engineers

Copying of material in this book for internal or personal use, or for the internal or personal use of specific clients, beyond the fair use provisions granted by the U.S. Copyright Law is authorized by SPIE subject to payment of copying fees. The Transactional Reporting Service base fee for this volume is $\$ 18.00$ per article (or portion thereof), which should be paid directly to the Copyright Clearance Center (CCC), 222 Rosewood Drive, Danvers, MA 01923. Payment may also be made electronically through CCC Online at copyright.com. Other copying for republication, resale, advertising or promotion, or any form of systematic or multiple reproduction of any material in this book is prohibited except with permission in writing from the publisher. The CCC fee code is 0277-786X/11/ \$18.00.

Printed in the United States of America.

Publication of record for individual papers is online in the SPIE Digital Library.

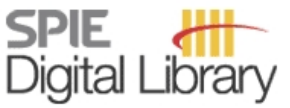

SPIEDigitalLibrary.org

Paper Numbering: Proceedings of SPIE follow an e-First publication model, with papers published first online and then in print and on CD-ROM. Papers are published as they are submitted and meet publication criteria. A unique, consistent, permanent citation identifier (CID) number is assigned to each article at the time of the first publication. Utilization of CIDs allows articles to be fully citable as soon as they are published online, and connects the same identifier to all online, print, and electronic versions of the publication. SPIE uses a six-digit CID article numbering system in which:

- The first four digits correspond to the SPIE volume number.

- The last two digits indicate publication order within the volume using a Base 36 numbering system employing both numerals and letters. These two-number sets start with $00,01,02,03,04$, $05,06,07,08,09,0 A, 0 B \ldots 0 Z$, followed by 10-1Z, 20-2Z, etc.

The CID number appears on each page of the manuscript. The complete citation is used on the first page, and an abbreviated version on subsequent pages. Numbers in the index correspond to the last two digits of the six-digit CID number. 


\title{
Contents
}

\author{
ix Conference Committee \\ xiii Introduction
}

SESSION 1 WAVELET PIONEER AWARD

805802 Intrinsic wavelet and frame applications (Invited Paper) [8058-01]

J. J. Benedetto, T. D. Andrews, Univ. of Maryland, College Park (United States)

\section{SESSION 2 WAVELETS APPLICATIONS I}

805803 Compressive sampling by artificial neural networks for video [8058-02]

H. SzU, U.S. Army Night Vision \& Electronic Sensors Directorate (United States); C. Hsu, Trident Systems Inc. (United States); J. Jenkins, U.S. Army Night Vision \& Electronic Sensors Directorate (United States); K. Reinhardt, Air Force Office of Scientific Research (United States)

805804 Classification of transient signals using sparse representations over adaptive dictionaries [8058-03]

D. I. Moody, Los Alamos National Lab. (United States) and Univ. of Maryland, College Park (United States); S. P. Brumby, K. L. Myers, N. H. Pawley, Los Alamos National Lab. (United States)

$805805 \quad$ Fractional wavelet transform using an unbalanced lifting structure [8058-04]

Y. H. Habiboğlu, K. Kose, A. E. Çetin, Bilkent Univ. (Turkey)

805806 Anomaly recovery from compressed spectral imagery via low-rank matrix minimization [8058-05]

A. Ramirez, H. Arguello, G. R. Arce, Univ. of Delaware (United States)

\section{SESSION 3 WAVELETS APPLICATIONS AND 3D SHEARLETS}

805807 Optimally sparse shearlet approximations of 3D data [8058-06]

D. Labate, Univ. of Houston (United States); K. Guo, Missouri State Univ. (United States)

805808 Three-dimensional shearlet edge analysis [8058-07]

D. A. Schug, Univ. of Maryland, College Park (United States); G. R. Easley, System Planning Corp. (United States); D. P. O'Leary, Univ. of Maryland, College Park (United States)

805809 Denoising medical imagery using a novel framework [8058-09]

S. P. Kozaitis, J. M. Mehta, S. Ponkia, Florida Institute of Technology (United States) 
8058 0A Application of wavelet transforms in de-noising optical emission transient signals generated from microsamples introduced into a microplasma and comparison with Fourier- and Hartley-transforms [8058-10]

D. Hunter, V. Karanassios, Univ. of Waterloo (Canada)

\section{SESSION 4 ICA UNSUPERVISED LEARNING AWARD}

8058 OB Filterbank-based independent component analysis for acoustic mixtures (Invited Paper) [8058-11]

H.-M. Park, Sogang Univ. (Korea, Republic of)

\section{SESSION 5 UNSUPERVISED LEARNING AND ICA}

8058 OD Robust speech recognition using missing feature theory and target speech enhancement based on degenerate unmixing and estimation technique [8058-13]

M. Kim, J.-S. Kim, H.-M. Park, Sogang Univ. (Korea, Republic of)

$8058 \mathrm{OE}$ Bioimaging and biospectra analysis by means of independent component analysis: experimental results [8058-14]

Q. Zhao, J. Langley, J. Lee, J. Abell, Y. Zhao, The Univ. of Georgia (United States)

8058 OF Human facial skin detection in thermal video to effectively measure electrodermal activity (EDA) [8058-15]

B. Kaur, J. A. Hutchinson, K. R. Leonard, U.S. Army Night Vision \& Electronic Sensors

Directorate (United States); J. K. Nelson, George Mason Univ. (United States)

\section{SESSION 6 APPLICATIONS AND NEURAL NETWORK LEARNING}

$8058 \mathrm{OH}$ Dynamic range compensation in non-linear sensors [8058-18]

H. Szu, U.S. Army Night Vision \& Electronic Sensors Directorate (United States); M. Wardlaw,

Office of Naval Research (United States); J. Willey, U.S. Naval Research Lab. (United States)

8058 Ol Generative and discriminant feature extraction with supervised learning [8058-19]

C. S. Dhir, S.-Y. Lee, KAIST (Korea, Republic of)

8058 0J Development of artificial neural networks for spectral interference correction in optical emission spectrometry [8058-20]

Z. Li, V. Karanassios, Univ. of Waterloo (Canada)

8058 OK A new approach for neural network training and evaluation with applications to sensing systems [8058-21]

X. Chen, E. Walker, Southern Univ. at Baton Rouge (United States)

\section{SESSION 7 NANO-ENGINEERING AWARD}

8058 OM Tip based robotic precision micro/nanomanipulation systems (Invited Paper) [8058-23]

C. Onal, B. Sumer, O. Ozcan, A. Nain, M. Sitti, Carnegie Mellon Univ. (United States) 
8058 ON Infrared imaging using carbon nanotube-based detector (Invited Paper) [8058-24] H. Chen, N. Xi, B. Song, L. Chen, K. W. C. Lai, Michigan State Univ. (United States); J. Lou, Xian Jiaotong Univ. (China)

805800 Catalytic nanomotors: challenges and opportunities [8058-25]

J. Gibbs, Y. Zhao, Univ. of Georgia (United States)

8058 OP Non-cryogenic cooled MWIR with swap-limited carbon nanotubes [8058-26]

H. Szu, U.S. Army Night Vision \& Electronic Sensors Directorate (United States); Y. L. Shen,

J. Wu, The George Washington Univ. (United States); K. Reinhardt, Air Force Office of

Scientific Research (United States)

\section{SESSION 9 PRESISTENT SURVEILLANCE I}

$80580 Q \quad$ How to build a smart sensing surveillance net [8058-27]

K.-D. Chu, U.S. Dept. of Homeland Security (United States); C. Hsu, Trident Systems Inc.

(United States)

8058 OR What is a missing link among wireless persistent surveillance? [8058-28]

C. Hsu, Trident Systems Inc. (United States); H. SzU, U.S. Army Night Vision \& Electronic Sensors Directorate (United States)

8058 OS Sequential principal component analysis [8058-29]

C. Hsu, Trident Systems Inc. (United States); H. SzU, U.S. Army Night Vision \& Electronic Sensors Directorate (United States)

8058 OT Spotting and tracking good biometrics with the human visual system [8058-30]

H. SzU, J. Jenkins, U.S. Army Night Vision \& Electronic Sensors Directorate (United States);

C. Hsu, Trident Systems Inc. (United States)

\section{SESSION 9A PRESISTENT SURVEILLANCE II}

8058 0V Distributed signal decorrelation in wireless sensor networks using the sparse matrix transform [8058-32]

L. R. Bachega, Purdue Univ. (United States); S. Hariharan, The Ohio State Univ. (United States); C. A. Bouman, Purdue Univ. (United States); N. Shroff, The Ohio State Univ. (United States)

$8058 \mathrm{OW} \quad$ Lossless divide and conquer for time-order sorting of $\mathbf{N}$ facial poses [8058-33]

M. K. Hsu, The George Washington Univ. (United States); H. Szu, U.S. Army Night Vision \& Electronic Sensors Directorate (United States)

SESSION 10 BIOMEDICAL WELLNESS AWARD FOR APPLYING COMPUTATIONAL INTELLIGENCE TO IMAGE DIAGNOSIS

$80580 X \quad$ Smart health management technology and its applications (Invited Paper) [8058-34]

H. Nakajima, Omron Corp. (Japan) 
8058 OY YURAGI: analysis for detecting heart-rate by mat-type sensor in bed [8058-35]

Y. Hata, Univ. of Hyogo (Japan) and Osaka Univ. (Japan); K. Ho, Univ. Of Hyogo (Japan);

K. Kuramoto, S. Kobashi, Univ. of Hyogo (Japan) and Osaka Univ. (Japan); N. Tsuchiya,

H. Nakajima, OMRON Corp. (Japan)

$80580 Z$ Visceral fat estimation method by bioelectrical impedance analysis and causal analysis [8058-36]

H. Nakajima, H. Tasaki, N. Tsuchiya, OMRON Corp. (Japan); T. Hamaguchi, T. Shiga, OMRON Healthcare Co., Ltd. (Japan)

805810 Blood vessel segmentation in magnetic resonance angiography imagery [8058-37]

S. P. Kozaitis, R. Chandramohan, Florida Institute of Technology (United States)

805811 Heart-rate monitoring by air pressure and causal analysis [8058-38]

N. Tsuchiya, H. Nakajima, OMRON Corp. (Japan); Y. Hata, Univ. of Hyogo (Japan)

805812 Biomedical wellness by tai chi and sports [8058-39]

D. C. Chin, The Johns Hopkins Univ., Retired (United States); A. G. Chin, Virginia

Commonwealth Univ. (United States)

805813 YURAGI: analysis for trans-skull brain visualizing by ultrasonic array probe [8058-52]

N. Yagi, Y. Oshiro, O. Ishikawa, Ishikawa Hospital (Japan); Y. Hata, Univ. of Hyogo (Japan) and Osaka Univ. (Japan); Y. T. Kitamura, T. Yanagida, Osaka Univ. (Japan)

805814 Biometrics security by dynamics of left and right sole pressure while walking [8058-57] T. Takeda, Univ. of Hyogo (Japan); K. Kuramoto, S. Kobashi, Y. Hata, Univ. of Hyogo (Japan) and Osaka Univ. (Japan)

805815 A fuzzy automated object classification by infrared laser camera [8058-58]

S. Kanazawa, Univ. of Hyogo (Japan); K. Taniguchi, Kinden Corp. (Japan); K. Asari, Kansai Electric Power Co., Inc. (Japan); K. Kuramoto, S. Kobashi, Y. Hata, Univ. of Hyogo (Japan) and Osaka Univ. (Japan)

\section{SESSION 12 SYSTEM BIOLOGY IMAGING PROCESSING}

805816 Defense-related insights and solutions from neuroscience and neuroengineering [8058-40]

A. Gunduz, New York State Dept. of Health (United States) and Albany Medical College (United States); G. Schalk, New York State Dept. of Health (United States), Albany Medical College (United States), and State Univ. of New York at Albany (United States)

805817 Wavelets for full reconfigurable ECG acquisition system [8058-41]

D. P. Morales, A. García, E. Castillo, Univ. de Granada (Spain); U. Meyer- Bäse, The Florida State Univ. (United States); A. J. Palma, Univ. de Granada (Spain)

805818 Wavelet domain analysis of EEG data for emotion recognition: evaluation of recoursing energy efficiency [8058-42]

T. H. Aspiras, V. K. Asari, Univ. of Dayton (United States) 
805819 Gaussian graphical modeling reveals specific lipid correlations in glioblastoma cells [8058-43]

N. S. Mueller, Max Planck Institut of Biochemistry (Germany); J. Krumsiek, F. J. Theis, Helmholtz Zentrum München GmbH (Germany); C. Böhm, Ludwig-Maximilians-Univ. München (Germany); A. Meyer-Bäse, The Florida State Univ. (United States)

8058 1A Gut feeling is electric [8058-44]

J. Familoni, U.S. Army Night Vision \& Electronic Sensors Directorate (United States)

8058 1B Reconstruction algorithms for optoacoustic imaging based on fiber optic detectors [8058-45]

H. Lamela, G. Díaz-Tendero, R. Gutiérrez, D. Gallego, Univ. Carlos III de Madrid (Spain)

8058 1C NIOS II processor-based acceleration of motion compensation techniques [8058-46] D. González, Univ. Complutense de Madrid (Spain); G. Botella, Univ. Complutense de Madrid (Spain) and Florida State Univ. (United States); S. Mookherjee, U. Meyer-Bäse, A. Meyer-Bäse, Florida State Univ. (United States)

8058 1D PCA method for automated detection of mispronounced words [8058-47]

Z. Ge, S. R. Sharma, M. J. T. Smith, Purdue Univ. (United States)

$8058 \mathrm{IE} \quad$ Optical flow optimization using parallel genetic algorithm [8058-48]

O. Zavala-Romero, G. Botella, A. Meyer-Bäse, U. Meyer Bäse, The Florida State Univ. (United States)

$8058 \mathrm{lF}$ Intellectual property protection (IPP) using obfuscation in C, VHDL, and Verilog coding [8058-49]

U. Meyer-Bäse, The Florida State Univ. (United States); E. Castillo, Univ. de Granada (Spain); G. Botella, The Florida State Univ. (United States); L. Parrilla, A. García, Univ. de Granada (Spain)

8058 IG Polarimetric detection for slowly moving/stationary targets in inhomogeneous environments [8058-50]

C. Hsu, H. Mendelson, A. Burgstahler, D. Hibbard, J. Faist, Trident Systems Inc. (United States)

$8058 \mathrm{1H}$ Independent component analysis (ICA) of fused wavelet coefficients of thermal and visual images for human face recognition [8058-17]

M. K. Bhowmik, Tripura Univ. (India); D. Bhattacharjee, D. K. Basu, M. Nasipuri, Jadavpur Univ. (India)

805811 Cellular defense processes regulated by pathogen-elicited receptor signaling (Invited Paper) [8058-51]

R. Wu, A. Goldsipe, D. B. Schaver, D. A. Lauffenburger, Massachusetts Institute of Technology (United States) 
$80581 \mathrm{~J}$ Ubiquitous-health (U-Health) monitoring systems for elders and caregivers [8058-53] G. Moon, K. Lim, Y. Yoo, H. An, K. S. Lee, Hallym Univ. (Korea, Republic of); H. Szu, U.S. Army Night Vision \& Electronic Sensors Directorate (United States)

$80581 \mathrm{~K}$ Solving channel assignment problems using local search methods and simulated annealing [8058-54]

L. Wang, S. N. S. Lee, W. Y. Hing, Nanyang Technological Univ. (Singapore)

$8058 \mathrm{lL} \quad$ Reverse engineering cellular decisions for hybrid reconfigurable network modeling [8058-55]

H. A. Blair, J. Saranak, K. W. Foster, Syracuse Univ. (United States)

$80581 \mathrm{M} \quad$ Approximate nearest neighbors via dictionary learning [8058-56]

A. Cherian, V. Morellas, N. Papanikolopoulos, Univ. of Minnesota, Twin Cities (United States)

8058 iN The physiology of keystroke dynamics [8058-59]

J. Jenkins, Q. Nguyen, J. Reynolds, W. Horner, H. Szu, U.S. Army Night Vision \& Electronic Sensors Directorate (United States)

Author Index 


\title{
Conference Committee
}

\author{
Symposium Chair
}

William Jeffrey, HRL Laboratories, LLC (United States)

Symposium Cochair

Kevin P. Meiners, Office of the Secretary of Defense (United States)

Conference Chair

Harold Szu, U.S. Army Night Vision \& Electronic Sensors Directorate

(United States)

Conference Cochair

Liyi Dai, U.S. Army Research Office (United States)

Program Committee

Shun-ichi Amari, RIKEN (Japan)

Hamid Bolouri, California Institute of Technology (United States)

Kenneth A. Byrd, U.S. Army Night Vision \& Electronic Sensors Directorate (United States)

Chee-Hung Chu, University of Louisiana at Lafayette (United States)

Kai-Dee Chu, U.S. Department of Homeland Security (United States)

Wen-Yan Danny Chung, Chung Yuan Christian University (Taiwan)

Andrzej S. Cichocki, Telcordia Technologies, Inc. (United States)

Ronald R. Coifman, Yale University (United States)

John Daugman, University of Cambridge (United Kingdom)

Qian Du, Mississippi State University (United States)

Glenn R. Easley, System Planning Corporation (United States)

John E. Gray, Naval Surface Warfare Center Dahlgren Division (United States)

Fredric M. Ham, Florida Institute of Technology (United States)

Yutaka Hata, University of Hyogo (Japan)

Charles C. Hsu, Trident Systems Inc. (United States)

Diana L. Huffaker, University of California, Los Angeles (United States)

Tzyy-Ping Jung, University of California, San Diego (United States)

Horacio Lamela, Universidad Carlos III de Madrid (Spain)

Joseph Landa, BriarTek, Inc. (United States)

Te-Won Lee, University of California, San Diego (United States)

Kevin W. Lyons, National Institute of Standards and Technology (United States) 
Uwe Meyer-Bäse, The Florida State University (United States)

Francesco Carlo Morabito, Università Mediterranea di Reggio Calabria (Italy)

Hairong Qi, The University of Tennessee (United States)

Jan-Olov Stromberg, Royal Institute of Technology (Sweden)

Mladen Victor Wickerhauser, Washington University in St. Lovis (United States)

Olaf Wolkenhaver, Universität Rostock (Germany)

Donald C. Wunsch II, Missouri University of Science and Technology (United States)

Ning Xi, Michigan State University (United States)

\section{Session Chairs}

1 Wavelet Pioneer Award

Harold Szu, U.S. Army Night Vision \& Electronic Sensors Directorate (United States)

2 Wavelets Applications I

John J. Benedetto, University of Maryland, College Park (United States)

Ronald R. Coifman, Yale University (United States)

3 Wavelets Applications and 3D Shearlets

John J. Benedetto, University of Maryland, College Park (United States)

$4 \quad$ ICA Unsupervised Learning Award

Soo-Young Lee, KAIST (Korea, Republic of)

Tzyy-Ping Jung, University of California, San Diego (United States)

5 Unsupervised Learning and ICA

Soo-Young Lee, KAIST (Korea, Republic of)

Hyung-Min Park, Sogang University (Korea, Republic of)

$6 \quad$ Applications and Neural Network Learning

Soo-Young Lee, KAIST (Korea, Republic of)

Takeshi Yamakawa, Kyushu Institute of Technology (Japan)

$7 \quad$ Nano-engineering Award

Harold Szu, U.S. Army Night Vision \& Electronic Sensors Directorate (United States)

$8 \quad$ Nano-engineering

Toshio Fukuda, Nagoya University (Japan)

Ning Xi, Michigan State University (United States) 
9 Presistent Surveillance I

Kai-Dee Chu, U.S. Department of Homeland Security (United States)

Charles Hsu, Trident Systems Inc. (United States)

9A Presistent Surveillance II

Kai-Dee Chu, U.S. Department of Homeland Security (United States)

Charles Hsu, Trident Systems Inc. (United States)

10 Biomedical Wellness Award for Applying Computational Intelligence to Image Diagnosis

Soo-Young Lee, KAIST (Korea, Republic of)

Hata Yutaka, University of Hyogo (Japan)

11 Biomedical Wellness Applications

Soo-Young Lee, KAIST (Korea, Republic of)

Takeshi Yamakawa, Kyushu Institute of Technology (Japan)

12 System Biology Imaging Processing

Henry Chu, University of Lovisiana at Lafayette (United States)

Jide Familoni, U.S. Army Night Vision \& Electronic Sensors Directorate (United States)

13 Engineering System of Systems and Application

Harold Szu, U.S. Army Night Vision \& Electronic Sensors Directorate (United States)

14 Systems Biology Pioneer Award

Harold Szu, U.S. Army Night Vision \& Electronic Sensors Directorate (United States)

15 Wellness Smart Sensors

Yutaka Hata, University of Hyogo (Japan)

Anke D. Meyer-Bäse, The Florida State University (United States) 
Downloaded From: https://www.spiedigitallibrary.org/conference-proceedings-of-spie on 26 Apr 2023

Terms of Use: https://www.spiedigitallibrary.org/terms-of-use 


\section{Introduction}

The tenth annual SPIE conference on Independent Component Analyses, Wavelets, Neural Networks, Biosystems and Nanoengineering, continues our yearly tradition of contributing and communicating knowledge to one another. The SPIE Defense Security and Sensing (DSS) Symposium has provided our community with the proper venue to exchange information, provide education through short courses, and network through various hospitality events. Boasting over 500 exhibiting vendors and talks given by over 7000 scientists and engineers worldwide, the symposium is an immense gathering. Our conference, however, is relatively small, but has a rapid dissemination of timely work in the disciplines covered. New to the conference this year is post-conference publication. We appreciate the timely submissions of our authors and the patience of our readers.

Being co-chairs, we often face questions about our goals and focus for the future of the conference series. To state the question plainly, how has the conference endured, and how can it continue to endure and evolve in a changing scientific environment? The answer lies partly in the following secret: We have adapted a workable system tested by the Nobel Foundation for over half a century-passing the baton of honor.... "The past award recipients shall determine the new awardees." The role SPIE and the co-chairs serve is to act as facilitators for the decision process. A major difference between the systems is a lack of recourse in supporting the awardees. Thus we have improvised a temporary win-win-win solution: in order to prepare the interdisciplinary audience, state of the art knowledge is disseminated by both past and present award recipients, who are encouraged to teach short courses at the meetings.

Driven by our desire to learn from nature, the SPIE conference on wavelets has evolved, and is now in its 18th year with SPIE. When the conference started 18 years ago progress began slowly. Then, year after year, knowledge began growing, building, and changing. The evolution of knowledge has led to a strong foundation for the work this year. The use of wavelets has seen much progress from a biomedical standpoint. From the 2011 Wavelet Pioneer Award Recipient Prof. John J. Benedetto (University of Maryland, College Park), we have learned how to apply the mathematical model of wavelets to explain natural phenomenon and applications to compressive sensing technology. Compressed sensing is a mathematical technique in which data is sparsely sampled by a series of zeros and ones, which acts like a "mask". Then the original data is reconstructed mathematically, a technique founded and developed by Candès, Romberg, Donoho, and Tao. Unsupervised learning uses artificial neural networks to imitate the human brain's ability to learn from previous data. The 2011 recipient of the Unsupervised Learning Neural Network Independent Component Analyses (ICA), Prof. Hyung-Min Park (Korea, Republic of), explains how ICA can be used to collect relevant acoustic data from acoustic mixtures. Decades of theoretical explanations have provided us with the means for experimental exploration and implementation. These experimental endeavors led to great progress by such efforts as applying computational intelligence to image

diagnosis done by the Biomedical Wellness award recipient Dr. Hiroshi Nakajima (OMRON Corp.). Experimental works from nanoengineers explore innovative methods for fabrication of exciting materials. We introduce our 2011 Nano-Engineering Pioneer Award recipient Prof. Metin Sitti (Carnegie Mellon University), who will provide insight from the field of nanorobotics. Nano-engineers can take advantage of the nanometer regime, in which unique physical and chemical properties not observed on a macroscale can be manipulated. Finally, we are ready to emulate the most robust, and 
perhaps most efficient field in its own right, System Biology, as elucidated by our 2011 Pioneer Award recipient Prof. Douglass A. Lauffenburger (MIT) during the last day of our program.

Lastly, compressive sampling is a relatively new technique and its application can be applied to a broad spectrum of disciplines. The committee has decided to acknowledge the pioneering efforts of compressive sensing in 2012 by Dai in the Army Research Office.

We wish to thank all of 2010 recipients, who headed the selection process for this year's awardees: Prof.Jan-Olov Stömberg, Prof. Yutaka Hata, Prof. Diana Huffaker, Soo-Young Li and Dr, Hamid Bolouri. The conference would not be a success without you and your unselfish contributions. We would also like to thank the SPIE technical support staff and last but certainly not least, I would like to thank the members of the program committee.

Harold Szu

Liyi Dai 